\title{
SURVIVAL IN TRAUMATIC SPINAL CORD INJURY
}

\author{
By W. O. Geisler ${ }^{1}$, M.D., F.R.C.P.(C), A. T. Jousse ${ }^{2}$, M.D., Megan \\ WYNNE-Jones ${ }^{3}$, M.D. and D. BREITHAUPT ${ }^{4}$, M.D. \\ ${ }^{1}$ Professor of Rehabilitation Medicine, University of Toronto and Senior Staff \\ Physician, Lyndhurst Hospital, ${ }^{2}$ Professor Emeritus Rehabilitation Medicine, \\ University of Toronto, Lyndhurst Hospital, ${ }^{3}$ Research Associate, Lyndhurst Hospital, \\ 520 Sutherland Drive, Toronto, Ontario $\mathrm{M}_{4} \mathrm{G}_{3} \mathrm{~V} 9 .{ }^{4}$ Medical Director, Manufac- \\ turers Life Insurance Co., 200 Bloor Street East, Toronto, Ontario $M_{4} W_{\text {I }} E_{5}$.
}

Summary. The present study was conducted on I5IO persons between I December I 973 and 3 I December I 980 . Of these, I 478 (97.9 per cent) were traced by questionnaire. Of those traced, 1252 were male and 226 were female. There were 194 deaths of whom I 60 were male and 34 female. The main causes of death are cardiovascular, renal, respiratory, suicide and neoplastic. Compared with the I973 study, there has been a marked decrease in deaths due to renal disease and a marked increase in deaths due to suicide and liver disease and the abuse of alcohol. A study of the new deaths allowed one to note a relative mortality rate to be I 86 per cent for partial paraplegics, 209 per cent for partial tetraplegics; 3 I 8 per cent for complete paraplegics and 767 per cent for complete quadriplegics. The approximate application of these rates to current (1975-77) mortality tables permitted the calculation of theoretically derived life expectation at various ages. These indicated an improved life expectation for all categories.

Key words: Traumatic spinal cord injury; Complications; Survival.

THIS STUDY is an extension of three earlier studies previously reported (Breithaupt et al. I96I; Jousse et al., I968; Geisler et al., I977). All studied life expectancy mortality rate and the causes of death of the spinal cord injured patient. The first (Breithaupt et al., I96I) reviewed 599 persons followed between I January I945, and 3I December I958, (published in I96I). It revealed genito-urinary sepsis as the chief cause of death and that the death rate of carefully treated spinal cord injured patients was three times that of the Ontario population mortality rate. In each of the four classes of spinal cord injury as defined by the level and completeness of the lesion, life expectancy was reduced when compared to the population mortality rate. It also revealed a dramatic reversal in the death rate over a period of more than a decade, compared to that reported prior to the Second World War. The second (Jousse et al., I 968) reviewed 965 patients followed from I January I 945, to 3 I December I 966 (published in I968), the leading cause of death was kidney failure which accounted for 36 per cent of the deaths. Once again it revealed the mortality rate to vary with the extent of the disease and also revealed a modest improvement in life expectancy. The third (Geisler et al., I 977) reviewed I 50 I patients followed from I January I 945 to 30 November I 973 (published in I977) -an interval of 29 years.

It included all of those studies on the two previous occasions. Of this number 428 ( 26 per cent) had died. Renal failure remained the leading cause of death as had been the case historically, however, its relative position 
TABLE I

Actual expected mortality comparison

\begin{tabular}{|c|c|c|c|}
\hline & 1958 & I966 & I973 \\
\hline Partial paraplegic & $195^{\circ} 0$ & I I $8^{\circ}{ }_{0}$ & $\mathrm{I} 8 \mathrm{I}_{0}^{0}$ \\
\hline Partial tetraplegic & $308^{\circ}$ & $216^{\circ}{ }_{0}^{\circ}$ & $223^{\circ}$ \\
\hline Complete paraplegic & $665^{\circ}$ & $400^{\circ}$ & $464^{\circ}$ \\
\hline Complete tetraplegic & $1758^{\circ} \circ$ & $1200^{\circ}$ & I I $63^{\circ} \%$ \\
\hline
\end{tabular}

TABLE II

Expectation of life (years)

partial and complete tetraplegic

\begin{tabular}{|c|c|c|c|}
\hline Age & I958 & I966 & I 973 \\
\hline \multicolumn{4}{|c|}{ Partial tetraplegic } \\
\hline 20 & 38 & 4I & 4I \\
\hline 30 & 30 & 32 & 32 \\
\hline 40 & 22 & 24 & 24 \\
\hline 50 & I4 & I6 & I 6 \\
\hline \multicolumn{4}{|c|}{ Complete tetraplegic } \\
\hline 20 & I 5 & $2 \mathrm{I}$ & $2 \mathrm{I}$ \\
\hline 30 & I I & I 6 & I6 \\
\hline 40 & 7 & IO & IO \\
\hline 50 & 3 & 5 & 5 \\
\hline
\end{tabular}

TABLE III

Expectation of life (years) parital and complete paraplegic

\begin{tabular}{cccc}
\hline Age & I958 & I966 & I973 \\
\hline \multicolumn{3}{l}{ Patrial } & paraplegic \\
20 & 42 & 45 & 42 \\
30 & 34 & 36 & 34 \\
40 & 25 & 28 & 25 \\
50 & I8 & 22 & I 8 \\
Complete paraplegic & \\
20 & 27 & 34 & 32 \\
30 & 20 & 27 & 25 \\
40 & I4 & I9 & I9 \\
50 & 8 & I2 & I2 \\
\hline
\end{tabular}

had fallen from 50 per cent in the first study to $30 \cdot 8$ per cent. A comparison of the relative mortality rates of the four classes showed that there had been no improvement in mortality between the second study completed in I 966 and the third study completed in 1973 (Table I). ${ }^{1}$

There was, in fact, some evidence of regression in the partial paraplegic class, possibly the result of the selective referral of more difficult partial lesions of the paraplegic type for management. The third study also revealed a substantially increased mortality within the group for the common causes of death, excepting accidental death, when compared to the population at large. Finally, a comparison of the expectation of life for the partial and complete categories of paraplegics and tetraplegics derived from the relative mortality rates showed no significant improvement had been achieved in the previous decade $\left(\right.$ Tables $\mathrm{II}^{2}$ and $\mathrm{III}^{3}$ ).

\section{Method}

The current study was extended to review all patients suffering traumatic spinal cord injury who had been treated at Lyndhurst for rehabilitation and discharged between I January 1945, and 3 I December I980. It excluded all exposure and deaths up until 30 November 1973.* These have been reported previously. ${ }^{1,2,3}$ It was from this group that we decided 
to look at the new deaths, so as to observe any variance from our observations of 1973. The whereabouts and status of the patients were determined by questionnaire.

A specific rate of mortality for male and female as the case might be depending upon his or her age at the time was added up for each year of exposure to give the expected deaths. The basis was the 1975-77 Province of Ontario Population Mortality rate tables. A table of expected duration of life was then calculated by the Actuarial Department of the Manufacturers Life Insurance Company, Toronto, from this same mortality table, using the relative mortality rates derived from the data.

\section{Results}

One thousand nine hundred and thirty-eight patients had been followed from I January I945, until 3 I December I980. All were traumatic spinal cord injured patients. Of this group 428 had died by the end of 30 November 1973. This left I5IO patients at the outset of the current study. Of this group 32 could not be traced ( $2 \cdot$ I per cent); I 478 were located $(97.9$ per cent). Of those traced 1252 were male and 226 were female. There were 194 new deaths, I60 male and 34 female (Table IV).

TABLE IV

I December 1973-3I December 1980

\begin{tabular}{lrrrrrrr}
\hline & Male & Female & Total & Deaths & Female deaths & Not traced \\
\hline Complete tetraplegic & 205 & 26 & 23 I & 33 & 2 & 3 \\
Partial tetraplegic & 336 & 60 & 396 & 48 & 8 & I 3 \\
Complete paraplegic & 340 & 82 & 422 & 55 & I 4 & 5 \\
Partial paraplegic & 37 I & 58 & 429 & 58 & IO & I I \\
Total & I252 & 226 & I478 & I94 & 34 & 32 \\
\hline
\end{tabular}

TABLE V

December 1973-December 1980

\begin{tabular}{|c|c|c|c|c|c|c|}
\hline & Lives & Life years & Actual & Expected & $\%$ & $\begin{array}{l}\text { Extra deaths } \\
\text { per I000/years }\end{array}$ \\
\hline \multicolumn{7}{|l|}{ Tetraplegic } \\
\hline Complete & $23 \mathrm{I}$ & I I 74.5 & 33 & $4 \cdot 3$ & 767 & $24 \cdot 4$ \\
\hline Partial & 396 & 2138 & 48 & $22 \cdot 9$ & 209 & I I $\cdot 7$ \\
\hline \multicolumn{7}{|l|}{ Paraplegic } \\
\hline Complete & 422 & 2420 & 55 & $17 \cdot 3$ & 318 & $15 \cdot 5$ \\
\hline Partial & 429 & $2064 \cdot 5$ & 58 & $3 \mathrm{I} .2$ & I 86 & 13.5 \\
\hline Total & I 478 & 7797 & I94 & $75 \cdot 7$ & 256 & I $5 \cdot 2$ \\
\hline
\end{tabular}

* All deaths within I 2 months of trauma were excluded, as was all exposure during the year of trauma and half of the exposure during the second year of trauma. Likewise, in the year of death, only half a year's exposure was included. 
On the exposure from December I 973 to December I980, the I 478 lives accounted for 7797 life years of spinal cord injury and I 94 deaths. During that time according to the 1975-77 Province of Ontario Population Mortality rate tables 75.7 deaths were expected. This results in a relative mortality rate of 2.56 ( 256 per cent) and can be expressed as 15.2 extra deaths per I000 life years for the overall group (Table V). The female deaths, 34 in number, showed mortality similar to the total group.

Furthermore, the table categorizes the patients according to the level and completeness of the lesion. The following are noted:

I. Complete tetraplegics: There were 23 I lives with I I74.5 life years of exposure. Thirty-three deaths were experienced when $4 \cdot 3$ were expected. This gave a relative mortality rate of 7.67 times normal ( 767 per cent) and can be expressed as 24.4 extra deaths per I000 life years.

2. Complete paraplegics: There were 422 lives with 2420 life years of exposure. Fifty-five deaths were experienced when only $17 \cdot 3$ were expected. This gave a relative mortality rate of $3 \cdot 18$ times normal ( 318 per cent) and can be expressed as 15.5 extra deaths per 1000 life years.

3. Partial tetraplegics: There were 396 lives with 2138 life years of exposure. Forty-eight deaths were experienced when 22.9 were expected. This gave a relative mortality rate of 2.09 times normal ( 209 per cent) and can be expressed as I I. 7 extra deaths per 1000 life years.

4. Partial paraplegics: There were 429 lives, giving $2064 \frac{1}{2}$ life years of exposure. Fifty-eight deaths were experienced when only $3 \mathrm{I} \cdot 2$ were expected. This gave a relative mortality of $\mathrm{I} \cdot 86$ times normal (I 86 per cent) and can be expressed as 13.5 extra deaths per 1000 life years.

The age of distribution at the time of the trauma is shown in Table VI. This reveals that over 75 per cent of the incidence occurs in the second to fourth decades of life. The peak incidence continues to be in the third decade, as previously noted. ${ }^{3}$ An analysis of the age distribution based upon the percentage of life years of exposure shows the predominent exposure to have been in the $3-5$ th decades (Table VII).

TABLE VI

Age at time of trauma

\begin{tabular}{crr}
\hline $\begin{array}{c}\text { Age } \\
\text { (years) }\end{array}$ & $\mathrm{N}$ & \multicolumn{1}{c}{${ }^{\circ}$} \\
\hline $0-9$ & $\mathrm{I}$ & $0 \cdot 6$ \\
IO-I9 & 279 & I $8 \cdot 8$ \\
$20-29$ & 593 & $40 \cdot \mathrm{I}$ \\
$30-39$ & 277 & I $8 \cdot 8$ \\
$40-49$ & I63 & I I 0 \\
$50-59$ & I I 4 & $7 \cdot 7$ \\
$60+$ & $5 \mathrm{I}$ & $3 \cdot 5$ \\
& I 478 & $99 \cdot 96$ \\
\hline
\end{tabular}


TABLE VII

Exposure December I973-December I980, study ( $\%$ of life years)

\begin{tabular}{|c|c|c|c|c|}
\hline $\begin{array}{c}\text { Age } \\
\text { (years) }\end{array}$ & $\begin{array}{l}\text { Complete } \\
\text { tetraplegia }\end{array}$ & $\begin{array}{l}\text { Complete } \\
\text { paraplegia }\end{array}$ & $\begin{array}{l}\text { Partial } \\
\text { tetraplegia }\end{array}$ & $\begin{array}{c}\text { Partial } \\
\text { paraplegia }\end{array}$ \\
\hline o-9 & 0 & 0 & - & $O \cdot I$ \\
\hline IO-I9 & $2 \cdot 4$ & I & $2 \cdot 3$ & $I \cdot 2$ \\
\hline $20-29$ & $33 \cdot I$ & I9 & 19.5 & I $2 \cdot 3$ \\
\hline $30-39$ & $3 I \cdot 3$ & $22 \cdot 9$ & $20 \cdot 6$ & $18 \cdot 5$ \\
\hline $40-49$ & I9.4 & $27 \cdot 4$ & $23 \cdot 2$ & $23 \cdot 3$ \\
\hline $50-59$ & 10.8 & I $8 \cdot 3$ & 16.6 & $24 \cdot 7$ \\
\hline $60-69$ & $2 \cdot 5$ & $8 \cdot 9$ & I I 5 & 12.9 \\
\hline $70-79$ & 0.5 & $2 \cdot 3$ & $5 \cdot 2$ & 49 \\
\hline $80-89$ & 0 & 0.2 & 0.9 & $2 \cdot 0$ \\
\hline \multirow[t]{2}{*}{$90+$} & 0 & 0 & 0.2 & $O \cdot I$ \\
\hline & $100^{\circ}{ }_{0}$ & $100^{\circ}{ }_{0}$ & $100^{\circ}{ }_{0}$ & $100^{\circ}{ }_{0}$ \\
\hline
\end{tabular}

TABLE VIII

Mortality years after trauma: complete tetraplegic

\begin{tabular}{lcccrr}
\hline & $\begin{array}{c}\text { Life years } \\
\text { exposure }\end{array}$ & Deaths & $\begin{array}{c}\text { Expected } \\
\text { deaths }\end{array}$ & $0^{\circ}$ & $\begin{array}{r}\text { Extra } \\
\text { D/M }\end{array}$ \\
\hline 2-5th years & 284 & I0 & 0.73 & I357 & $32 \cdot 6$ \\
6-IOth years & 318.5 & 5 & 0.85 & 585 & I3.0 \\
I I-I 5th years & 242 & 2 & 0.56 & 35 I & $5 \cdot 9$ \\
I6 + years & 330 & I6 & I.98 & 805 & $42 \cdot 4$ \\
\hline
\end{tabular}

TABLE IX

Mortality years after trauma: partial tetraplegic

\begin{tabular}{|c|c|c|c|c|c|}
\hline & $\begin{array}{l}\text { Life years } \\
\text { exposure }\end{array}$ & Deaths & $\begin{array}{l}\text { Expected } \\
\text { deaths }\end{array}$ & $\mathrm{o}_{0}$ & $\begin{array}{l}\text { Extra } \\
D / M\end{array}$ \\
\hline $2-5$ th years & 400 & 5 & $2 \cdot 6$ & I 86 & $5 \cdot 7$ \\
\hline 6-Ioth years & 455 & 6 & $2 \cdot 9$ & 205 & $6 \cdot 7$ \\
\hline I I-I 5 th years & 450 & IO & $4 \cdot 5$ & 219 & I $2 \cdot I$ \\
\hline I6 + years & 833 & 27 & I $2 \cdot 7$ & 2 I I & I $7 \cdot \mathrm{I}$ \\
\hline
\end{tabular}

It is interesting to note that the younger years predominate in the more severe lesions and the older years in the less severe lesions.

Considering the number of years after the trauma, if one divides the mortality according to the years of duration of spinal injury then one has an opportunity to note where the extra mortality is.

I. Complete tetraplegics: (3 of 23 I lives were not traced) (Table VIII). 
SURVIVAL IN TRAUMATIC SPINAL CORD INJURY

TABLE X

Mortality years after trauma: complete paraplegic

\begin{tabular}{lccccr}
\hline & $\begin{array}{c}\text { Life years } \\
\text { exposure }\end{array}$ & Deaths & $\begin{array}{c}\text { Expected } \\
\text { deaths }\end{array}$ & ${ }^{\circ}{ }_{0}$ & $\begin{array}{c}\text { Extra } \\
\text { D } / \mathbf{M}\end{array}$ \\
\hline 2-5th years & 332 & 4 & $0 \cdot 9$ & 4 I 8 & $9 \cdot$ I \\
6-IOth years & 506 & I2 & $2 \cdot 2$ & 528 & I9.2 \\
I I-I 5th years & $408 \cdot 5$ & 8 & $2 \cdot 3$ & 335 & I3.7 \\
I6 + years & I I 73.5 & 3 I & I I.6 & 265 & I6.4 \\
\hline
\end{tabular}

TABLE XI

Mortality years after trauma: partial tetrapegic

\begin{tabular}{lcccrr}
\hline & $\begin{array}{c}\text { Life years } \\
\text { exposure }\end{array}$ & Deaths & $\begin{array}{c}\text { Expected } \\
\text { deaths }\end{array}$ & ${ }^{\circ}{ }_{0}$ & $\begin{array}{r}\text { Extra } \\
\text { D/M }\end{array}$ \\
\hline 2-5th years & $325 \cdot 5$ & 3 & I. I & 258 & $5 \cdot 6$ \\
6-IOth years & 459 & 8 & $3 \cdot 0$ & 263 & I0.8 \\
I I - I 5th years & 384.5 & 7 & $4 \cdot 4$ & I 56 & $6 \cdot 4$ \\
I6 + years & I 269 & 40 & $\mathbf{2 2} \cdot 2$ & I 79 & I 3.9 \\
\hline
\end{tabular}

TABLE XII

Deaths

\begin{tabular}{|c|c|c|}
\hline & I973 & I980 \\
\hline Renal & $30 \cdot 8$ & $15 \cdot 3$ \\
\hline Cardiovascular & $20 \cdot 4$ & 19.6 \\
\hline Respiratory & $12 \cdot 2$ & 13.9 \\
\hline Neoplastic & $9 \cdot 8$ & $9 \cdot 8$ \\
\hline Cerebrovascular & $6 \cdot 8$ & $4 \cdot 6$ \\
\hline Suicide & $4 \cdot 2$ & $10 \cdot 8$ \\
\hline Liver/Alcohol & $\mathrm{I} \cdot 2$ & $4 \cdot I$ \\
\hline Other & 15.6 & $26 \cdot 9$ \\
\hline Total & $100^{\circ}$ & $100^{\circ}$ \\
\hline Total deaths & 428 & I94 \\
\hline
\end{tabular}

The mortality is high in the $2-5$ th year and in the 16 th and over years and it is lower in the 6-IOth and I I-I 5 th years after trauma.

2. Partial tetraplegics: ( 13 of 409 lives were not traced) (Table IX). The mortality is a little higher between the I Ith and I 5 th and beyond the I6th years.

3. Complete Paraplegics: ( 5 of 427 lives were not traced) (Table X). The mortality is a little higher from the 6-Ioth year. The mortality is relatively constant in all durations.

4. Partial paraplegics: (I I of 440 lives were not traced) (Table XI). The mortality appears to be higher in the 6-Ioth year after injury and also beyond the i6th year. 
5. These figures indicate that there is extra mortality in all duration. It is especially high in the complete tetraplegics from the $2-5$ th years -and in the complete paraplegics from the 6-Ioth years and again in both complete categories after the I6th year.

Table XII compares the incidence of the common causes of death in I 973 and present study.

Concerning the I 980 deaths, the category 'other' included deaths from the following causes-homicide; accidents; diabetes; incarcerated ventral hernia; perforated bowel; infections of bone and decubitii; septicaemia; G.I. hernia, bowel necrosis and gangrene of the gallbladder. The renal deaths were attributable to pyelonephritis, uremia, amyloidosis, and iliac conduit surgery, complicated by peritonitis. The cardiovascular deaths included myocardial infarction; heart failure, cardiac arrest; myocarditis; pulmonary embolism; mesenteric thrombosis; aortic stenosis and ruptured abdominal aneurysm. The respiratory deaths included pneumonia, pulmonary oedema; respiratory failure and death due to chronic obstructive lung disease.

It is known that the commonest causes of death in the normal population, excluding accidental causes, are heart disease; cancer; suicide and respiratory disease.

Table XIII reveals the actual incidence of these causes in the spinal injured and compares them to the expected incidence in the normal population. Renal diseases have been excluded.

What appears significant following an analysis of Tables XII and XIII is the marked decrease in deaths due to renal disease, and a marked increase in deaths due to suicide, liver disease, and an abuse of alcohol. A constant incidence of deaths due to cardiovascular, respiratory and neoplastic disease is noted. Regarding deaths due to neoplastic disease, the organ distribution is widespread: lung (five), G.I. (five), pancreas (two), and one instance each of metastatic, abdomen, breast, gallbladder, nasopharynx, vulva, lymphosarcoma, and leukaemia. The data does not now suggest that the spinal

TABLE XIII

Commonest causes of death (excluding renal)

\begin{tabular}{lcccc}
\hline $\begin{array}{c}\text { Complete } \\
\text { tetraplegia } \\
\text { 23 I }\end{array}$ & $\begin{array}{c}\text { Complete } \\
\text { paraplegia } \\
422\end{array}$ & $\begin{array}{c}\text { Partial } \\
\text { tetraplegia } \\
396\end{array}$ & $\begin{array}{c}\text { Partial } \\
\text { paraplegia } \\
429\end{array}$ \\
\hline Actual deaths & 33 & 55 & 48 & 58 \\
Expected deaths & $4 \cdot 3$ & $\mathbf{1 7} \cdot 2$ & $22 \cdot 9$ & $3 \mathrm{I} \cdot 2$
\end{tabular}

Actual Expected Actual Expected Actual Expected Actual Expected

\begin{tabular}{|c|c|c|c|c|c|c|c|c|}
\hline $\begin{array}{l}\text { Respiratory } \\
\text { disease }\end{array}$ & I I & 0.3 & 7 & 0.7 & 6 & $I \cdot O$ & 3 & $I \cdot I$ \\
\hline Heart & & & & & & & & \\
\hline disease & 4 & $\mathrm{I} \cdot 4$ & I 2 & $7 \cdot 7$ & 8 & $9 \cdot 8$ & I 4 & $12 \cdot 7$ \\
\hline Suicide & 4 & $I \cdot O$ & 4 & $2 \cdot 4$ & 5 & $2 \cdot I$ & 8 & $2 \cdot 4$ \\
\hline Cancer & 3 & $I \cdot 3$ & 6 & $6 \cdot I$ & 6 & $6 \cdot 7$ & 4 & $8 \cdot 7$ \\
\hline
\end{tabular}


TABLE XIV

Expectation of life (years) partial and complete tetraplegic

\begin{tabular}{lrr}
\hline Age & I973 & I980 \\
\hline Partial paraplegia & & \\
20 & 4 I & 44 \\
30 & 32 & 36 \\
40 & 24 & 27 \\
50 & I6 & I 8 \\
Complete paraplegia & & \\
20 & 2 I & 30 \\
30 & I6 & 23 \\
40 & IO & I5 \\
50 & 5 & 9 \\
\hline
\end{tabular}

\section{TABLE XV}

Expectation of life (years) partial and complete paraplegic

\begin{tabular}{lll}
\hline Age & I973 & I980 \\
\hline Partial paraplegia & & \\
20 & 42 & 46 \\
30 & 34 & 37 \\
40 & 25 & 28 \\
50 & I 8 & I9 \\
Complete paraplegia & & \\
20 & 32 & 40 \\
30 & 25 & 32 \\
40 & I9 & 23 \\
50 & I2 & I5 \\
\hline
\end{tabular}

injured population are at a significantly increased risk to the development of cancer as had been earlier supposed.

Based upon the present relative mortality rates related to the level and completeness of the lesion, a table of theoretical or derived expectation of life was tabulated by the Actuarial Department of the Manufacturers Life Insurance Company at ages 20,30, 40 and 50 years, using the 1975-77 Province of Ontario Population Mortality rate tables. These figures appear in Tables XIV and XV where they are compared with the earlier study. These tables indicate an improved life expectation for all categories regardless of the level of the lesion or the degree of completeness of the lesion.

\section{Discussion}

Our patients were not treated with intermittent catheterisation except in a 
few instances. This data reveals that spinal cord injured patients who have been discharged from a rehabilitation hospital continue to have a higher mortality rate than the population at large. It is highest for the complete lesions and lower for the partial lesions. In the complete category it is still very high for the tetraplegic ( 767 per cent). Nevertheless, comparing the relative mortalities now (I980) with those which were obtained in the study of I973, mortality is down (excepting partial paraplegics, where it is relatively constant) and life expectancy has been prolonged. This is especially so in the complete lesions. That the incomplete categories do not appear to have been as greatly advantaged with time and treatment may point to their starting out better to begin with, or to the importance of even a small amount of continuity of spinal cord function in allowing the body a more normal homeostasis. This might offer a correspondingly more favourable protection against the risks leading to death. Accordingly their relative mortality rates are closer to those of the normal population. The continued high rates for the complete categories are not unexpected. However, it is gratifying to see a decline from earlier observations.

In looking for an explanation one is struck by the large decrease in deaths due to renal disease. Mindful that intermittent catheterisation was not practiced in the vast majority, we would speculate the following:

Perhaps improved knowledge in the fields of antibiotics, renal dialysis and in medical and surgical expertise, may be of significance. Furthermore, the educational impact of rehabilitation may be bearing fruit. Perhaps patients and their attendants and life associates are learning more about the prevention of complications and applying those lessons well.

It seems unlikely that the spinal population is at any greater risk of death due to heart disease or cancer than the population at large. However, deaths due to respiratory disease and suicide are alarmingly high when compared to the normal population and would appear to be significantly so. These require further attention, as do deaths from liver disease and the abuse of alcohol.

\section{Conclusion}

Mortality has been decreased and life expectation prolonged in traumatic spinal injured patients.

\section{Acknowledgments}

The authors are most grateful for the assistance of: The Candian Paraplegic Association; The Equifax Services Ltd, for following up those who did not reply to the questionnaire; The Actuarial Department of the Manufacturers Life Insurance Company and particularly to Mr J. L. Cummins, F.S.A. and Mr A. C. Muirhead-Gould, F.S.A. for advice in preparing the figures.

\section{RÉSUMÉ}

L'étude actuelle a été effectuée sur I5IO personnes entre le ler. décembre I973 et le 3I décembre 1980. D'entre celles-ci, I 478 (97,9 pour cent) ont été tracées par questionnaire. Des personnes qu'on a tracées, I 252 étaient mâles et 226 femelles. Il y a eu 194 morts dont 160 étaient mâles et 34 femelles. Les causes principales de mort sont d'origine 
cardio-vasculaire, rénale, respiratoire et néoplastique ainsi que la suicide. En comparaison avec l'étude entreprise en 1973, il y a eu une diminution marquée des morts dues aux maladies rénales et une augmentation marquée des morts dues à la suicide, aux maladies du foie et à l'abus de l'alcool. Une étude des nouvelles morts a permis de noter que le taux de mortalité rélatif est de i 86 pour cent pour les paraplégiques partiels, de 209 pour cent pour les tétraplégiques partiels, de 3 I 8 pour cent pour les paraplégiques complets, et de 767 pour cent pour les quadriplégiques complets. L'application approximative de ces taux aux tableaux de mortalité actuels (1975-77) a permis la calculation de l'espérence de vie théoriquement dérivée à des âges divers. Ces chiffres indiquaient une espérance de vie améliorée pour toutes les catégories.

\section{ZUSAMMENFASSUNG}

Die jetzige Untersuchung betraf i 5 io Personen, und wurde zwischen dem I. Dezember I 973 und dem 3I. Dezember I980 durchgeführt. Aus diesen Personen sind I478 (97,9 Prozent) durch Fragebogen nachgesucht worden. Aus den Nachgesuchten waren 1252 männlich und 226 weiblich. Es waren I 94 Todesfälle wovon I 60 Fälle männliche und 34 weibliche Personen betrafen. Die hauptsächlichen Todesursachen sind Kardiogefäss-, Nieren- und Atmungskrankheiten, Selbstmord und neoplastische Krankheit. Im Vergleich zu der in 1973 durchgeführten Untersuchung hat sich eine deutliche Verminderung der durch Nierenkrankheit verursachten Todesfälle gezeigt, aber auch eine deutliche Steigung der Todesfälle, die durch Selbstmord, Leberkrankheit und Alkoholmissbrauch verursacht worden sind. Eine Untersuchung der neuen Todesfälle hat es ermöglicht, zu beobachten, dass das relative Sterblichkeitsverhältnis I 86 Prozent für die durch teilweise Paraplegie Getroffenen, 209 Prozent für die durch teilweise Tetraplegie Getroffenen, 3 I 8 Prozent für die durch völlige Paraplegie Getroffenen, und 767 Prozent für die durch völlige Quadriplegie Getroffenen beträgt. Die approximative Anwendung von diesen Verhältnissen auf die aktuellen (1975-77) Sterblichkeitstabellen hat die Berechnung der theotetisch hergeleiteten mutmasslichen Lebensdauer in verschiedenen Altern ermöglicht. Diese Ziffern zeigten eine verbesserte mutmassliche Lebensdauer für sämtliche Kategorien.

\section{REFERENCES}

Breithaupt, D. J., Jousse, A. T. \& Wynne-Jones, M. (I96I). Late cause of death and life expectancy in paraplegia. C.M.A.F., 85, 73-77.

Jousse, A. T., Wynne-Jones, M. \& Breithaupt, D. J. (1968). A follow-up study of life expectancy and mortality in Traumatic Transverse Myelitis. C.M.A.F., 98, 770-772.

Geisler, W. O., Jousse, A. T. \& Wynne-Jones, M. (I977). Survival in Traumatic Transverse Myelitis. Paraplegia, 14, 262-275. 